Egyptian Journal of Aquatic Biology \& Fisheries

Zoology Department, Faculty of Science,

Ain Shams University, Cairo, Egypt.

ISSN $1110-6131$

Vol. 25(2): $237-251$ (2021)

www.ejabf.journals.ekb.eg

\title{
The Impact of Sea Cucumber Symbiont Bacteria Bacillus aquimaris and Virgibacillus chiguensis on Meat Quality of Salem Fish (Scomber japonicus)
}

\section{Delianis Pringgenies $^{1 *}$, Gunawan Widi Santosa $^{1}$, Ervia Yudiati ${ }^{1}$, Ali Djunaedi ${ }^{1}$, Dafit Ariyanto ${ }^{2}$}

${ }^{1}$ Departement of Marine Science, Faculty of Fisheries and Marine Science, Diponegoro University, Jl. Prof. Soedarto, SH. Kampus UNDIP Tembalang, Semarang, Central Java, 50275, Indonesia

${ }^{2}$ Departement of Aquaculture, Faculty of Agriculture, Asahan University, J1 Ahmad Yani, Kisaran, North Sumatera, 21224, Indonesia

*Corresponding Author: delianispringgenies@lecture.undip.ac.id

\begin{tabular}{ll} 
ARTICLE INFO & \multicolumn{1}{c}{ ABSTRACT } \\
Article History: & $\begin{array}{l}\text { One of the reasons of low fish meat quality is attributed to enzymes, } \\
\text { biochemical reactions, and bacterial activities, which produce histamine. One } \\
\text { Received: Dec. 13. 2020 } \\
\text { Accepted: March 30, 2021 } \\
\text { Online: April 6, 2021 } \\
\text { enzyme is Bacillaceae, which is commonly found in the digestive system of sea } \\
\text { cucumbers. Based on the facts mentioned above, this study was presented to } \\
\text { determine the potential of Bacillus aquimaris and Virgibacillus chiguensis in } \\
\text { delaying the degradation of the Pacific mackerel's (Scomber japonicus) meat }\end{array}$ \\
Keywords: & $\begin{array}{l}\text { quality. Several methods were employed during the study to guarantee the } \\
\text { safety of meat for consumption, based on its chemical and microbiological } \\
\text { characteristics. The methods employedin the current study were: organoleptic }\end{array}$ \\
B. aquimaris, & $\begin{array}{l}\text { assessment, measurement of acidity, total plate count (TPC), proximate test, } \\
\text { total volatile base (TVB) analysis, trimethylamine (TMA-N) analysis, histidine }\end{array}$ \\
fish meat, & $\begin{array}{l}\text { analysis, histology of fish meat, and HDC gene analysis. Based on the quality of } \\
\text { fish meat (morphology, structure, proximate contents, histidine content, and } \\
\text { texture, }\end{array}$ \\
TPC, & $\begin{array}{l}\text { histology), V. chiguensis had the best potential as a bactericidal agent against } \\
\text { multidrug resistance (MDR) pathogenic strain bacteria compared to B. } \\
\text { aquimaris and the bacterial consortium, making it the most promising candidate } \\
\text { to chiguensis }\end{array}$
\end{tabular}

\section{INTRODUCTION}

The Sea cucumber is a detritivore which makes the seabed its natural habitat. This marine life consumes sediments, such as sand, and absorbs organic nutrients using its digestive tract (Zhang et al., 2012; Pringgenies et al., 2018). The aforementioned feeding process exposes the sea cucumber to the risk of bacterial infection from its immediate surroundings. Several symbiont bacteria found in Holothuria atra and 
Holothuria leucospilota, such as the methicillin-resistant Staphylococcus aureus (MRSA) and the extended spectrum $\beta$-Lactamase (ESBL) Escherichia coli, have been known to inhibit the growth of multi drug resistance (MDR) pathogenic strain. Molecular identification of these symbiont bacteria determined that these species are Bacillus aquimaris and Virgibacillus chiguensis (Ibrahim, 2012; Pringgenies et al., 2019; Santosa et al., 2020).

Pacific mackerel (Scomber japonicus) is a member of the Scombridae family which lives in epipelagic waters, or in approximately 50 meters under the surface of the ocean (Hernández \& Ortega, 2000; Allaya et al., 2013). This species is widely consumed, especially by members of the community from the middle to lower income bracket, due to its affordable price and good taste. This fish is generally processed using a simple method which results in a limited range of products. The most prevalent issue in the processing of fish meat is that the quality of the meat deteriorates rapidly. This issue is attributed to the existence of bio-degrading bacteria in the meat, among which is $E$. coli. These bacteria break down protein for their own growth, which affects the color, texture, odor, and the acidity of the meat (Farouk $\boldsymbol{e t}$ al., 2007).

In the process of microbial bio-degradation, meat releases histamine. This phenomenon is especially apparent in fish of Scombridae family, when bacteria produce histidine decarboxylase (HDC) which turns free histidine into histamine (Kanki et al., 2007). Histamine is an active primary heterocyclic biological compound in fish meat (Nahla \& Farag, 2005). High histamine content can cause toxicity in humans (FAO/WHO, 2012). Several known HDC-producing bacteria come from Enterobacteriaceae and Bacillaceae family.

A preservation process is needed to slow down fish meat deterioration rate, yet only a few preservation techniques have been applied so far. Supernatant with secondary metabolites from $B$. aquimaris and $V$. chiguensis is used to enhance meat quality and inhibit the synthesis of HDC. This process is employed because according to Brillantes et al. (2002), there are several compounds which can inhibit the rate of histamine production, making a further exploration on this finding that is necessary for the discovery of new preservative materials. This research aimed to determine the potential of B. aquimaris and V. Chiguensis in their application as preservatives for Pacific mackerel meat. The supernatant was used in an immersion process in order to allow the compound to be incorporated into the meat tissue. The potential of the compounds was measured by chemical assay, microbiological assessment, organoleptic assessment, and HDC gene detection.

\section{MATERIALS AND METHODS}

\section{Sample Collection}

Specimen of fresh sea cucumber Holothuria atra and Holothuria leucospilota were collected from Bandengan waters, Jepara, Indonesia during May - August 2020. Bacterial isolation was conducted in Tropical Marine Biotechnology Laboratory, Faculty 
of Fisheries and Marine Science, Diponegoro University. The samples were kept in polyethylene plastic bags (Whir-pak, Nasco, USA) and placed in a coolbox.

\section{Research Procedures}

Bacterial Colony Cultivation, Immersion Test of Supernatants of B. aquimaris and V. chiguensis

$10 \mathrm{ml}$ of Zobell liquid media was placed in centrifuge tubes that were sterilized using the autoclave at $121{ }^{\circ} \mathrm{C}$ for 20 minutes. The bacteria of B. aquimaris and $V$. chiguensis were cultured and shaken at $120 \mathrm{rpm}$ for 5 days to accumulate the resulting secondary metabolites in the media (Fitri et al., 2017). The bacterial cultures were centrifuged at $3000 \mathrm{rpm}$ for 10 minutes to separate the supernatant-laden media from its bacterial suspension. A weight of $30 \mathrm{~g}$ of Pacific mackerel meat, which had been prepared in fillets, was placed in petri dishes. The treatments employed in the immersion test used the supernatants of B. aquimaris, V. chiguensis, sterilized Zobell liquid media, with no immersion. The supernatants were poured over the fillets till immersion. The sterilized media for immersion and no immersion treatments were used as control groups. The fillets were immersed for 2 hours at $4{ }^{\circ} \mathrm{C}$ following the method of Deviyanti $\boldsymbol{e t}$ al. (2015).

\section{Organoleptic Assessment}

The organoleptic assessment in this study consisted of observations on texture, color, and odor of the samples from each treatment group and control group. The scoring was performed by 10 untrained individuals using questionnaires. The acidity of the meat was measured using $\mathrm{pH}$ paper with 3 iterations for each treatment group. The bacterial colony count was tallied using the total plate count method. Seeding for TPC were the results of $10^{-3}, 10^{-4}$, and $10^{-5}$ dilutions and were seeded using spread plate technique. The incubation period for the TPC was 3 days at $37{ }^{\circ} \mathrm{C}$ to allow the bacteria to grow. Proximate test includes water, ash, protein, fat, and carbohydrate contents according to AOAC (2005). Meanwhile, total volatile base (TVB-N) analysis and trimethylamine (TMA-N) analysis were conducted using Idakwo et al. (2016) as reference.

\section{Histidine Analysis}

The histidine analysis was performed according to the methods used in Takahashi and Tezuka (1997). $1 \mathrm{~g}$ of meat sample was pulverized and homogenized by adding $100 \mathrm{ml}$ of distilled water. $5 \mathrm{ml}$ of homogenized sample was placed into an erlenmeyer flask. $0.5 \mathrm{ml}$ of $2 \mathrm{~N}$ sulfic acid was added into the flask, then the mixture was left for 15 minutes. $0.25 \mathrm{~g}$ of bromine was added into the prepared sample. The mixture was left in a dark room for 2.5 hours. Afterwards, 5 - $6 \mathrm{ml}$ of arsenate reagent was added and the mixture was homogenized before adding $2.5 \mathrm{ml}$ of acetate solution. The mixture was diluted with cold $\left(4{ }^{\circ} \mathrm{C}\right)$ distilled water to a volume of $10 \mathrm{ml}$. The prepared sample was then measured using a spectrophotometer at $540 \mathrm{~nm}$ wavelength. 


\section{Histology of Fish Meat}

A portion of the fish meat was immersed in a formalin solution to prevent decomposition. The sample was then fixated in $10 \%$ BNF solution for $3 \times 24$ hours, after which it was diced, placed in a tissue cassette and dehydrated in an alcohol solution with a gradual increase in concentration. The sample was purified in xylol and embedded in paraffin, and then, cut into $4 \mu \mathrm{m}$ thickness with a microtome. The slices were carefully placed onto an object glass, immersed in hot water, and left to simmer. The prepared sample was incubated at $52{ }^{\circ} \mathrm{C}$ for 24 hours. Coloration was performed using xylol, $100 \%$ alcohol, hematoxylin and eocyn solutions. The preparation was then observed under a microscope (Tinacci et al., 2018).

\section{HDC Gene Analysis}

The cultivation of fish meat bacteria used $18 \mathrm{ml}$ of Zobell $2216 \mathrm{E}$ liquid media to immerse $2 \mathrm{~g}$ of pulverized fish meat. The prepared sample was shaken at $120 \mathrm{rpm}$ for 48 hours. Then, it was centrifuged at $6000 \mathrm{rpm}$ for 10 minutes. The resulting supernatant was removed, and the bacteria were suspended at the bottom of the centrifuge tube (Malenfanta et al., 2019). 10-25 g of bacterial sample was taken and placed in a $1.5 \mathrm{ml}$ micro tube. $100 \mu \mathrm{l}$ of $\mathrm{ddH}_{2} \mathrm{O}$ and $1 \mathrm{ml}$ of $0.5 \%$ saponin in $1 \mathrm{x}$ PBS were added, and the micro tube was stored at a temperature of $4{ }^{\circ} \mathrm{C}$ for 12 hours. The micro tube was then centrifuged at $12.000 \mathrm{rpm}$ for 10 minutes, after which the resulting supernatant was removed. $1 \mathrm{ml}$ of $1 \mathrm{x}$ PBS was added, and the mixture was centrifuged at $12.000 \mathrm{rpm}$ for 5 minutes, after which the resulting supernatant was removed. $100 \mu \mathrm{l}$ of $\mathrm{ddH}_{2} \mathrm{O}$ and $50 \mu \mathrm{l}$ of $20 \%$ Chelex ${ }^{\circledR} 100$ were added into the prepared sample. The sample was then heated for 10 minutes, which was vortexed in the first 5 minutes. The prepared sample was placed back into the centrifuge at $12.000 \mathrm{rpm}$ for 5 minutes, after which the resulting supernatant was transferred to a fresh micro tube. The sample was then stored at a temperature of $-20{ }^{\circ} \mathrm{C}$ (Phillips et al., 2012)

\section{Amplification of Bacteria DNA}

The polymerase chain reaction (PCR) method was employed in DNA amplification in accordance with Radjasa et al. (2001). The primers used were hdc forward (5'-TCH ATY ARY AAC TGY GGT GAC TGG RG-3') and hde reverse (5'CCC ACA KCA TBA RWG GDG TRT GRC C-3') with a base length of 709 bp. The materials used were hdc forward and hdc reverse primers, each $2 \mu 1,2.5 \mu 1$ of extract of sample DNA, $6 \mu \mathrm{l}$ of ddH2O, and $12.5 \mu$ l of Promega's GoTaq ${ }^{\circledR}$ DNA Polymerase. The protocol of PCR amplification in this study included 5 minutes of pre-denaturation at 94 ${ }^{\circ} \mathrm{C}, 1$ minute of denaturation at $94{ }^{\circ} \mathrm{C}, 1$ minute of annealing at $58{ }^{\circ} \mathrm{C}$, and 1 minute of extension at $70{ }^{\circ} \mathrm{C}$. The cycle was performed in 35 iterations. 


\section{Electrophoresis and Visualization}

The electrophoresis was achieved through an induction of electrical current, so that the DNA shifted towards the opposing polar. The materials used were $1 \%$ agarose gel diluted in 1x TAE buffer. $5 \mu$ l of DNA sample was injected into one gel well and $1 \mu \mathrm{l}$ of DNA marker was injected into the other well. Electrical current at 100 Volts was inducted for 35 minutes. Hence, the DNA fragment separated. The electrophoresis result was visualized using UV Gel Documentation. The DNA band was highlighted upon being exposed to UV light (Suzuki et al., 1993).

\section{RESULTS}

\section{Organoleptic Assessment}

The meat with VC immersion treatment was given the highest score at 7.25 , and the lowest was given to that of TP immersion treatment at 5.25 (Table 1). Based on the results, the treatment correlated to the resulting texture. VC, BA, AC and MS treatments resulted in better texture scores compared to those of the TP. The score awarded by each panelist indicated that the meat with treatment had more tender texture, compared to the meat with no treatment, which resulted in a lack of elasticity. This result was attributed to the activity of contaminant bacteria during storage. The scores of meat texture, odor, color, after 2 hours of immersion treatment, are presented in Tabel (1).

Table 1. The scores of meat texture, odor, color

\begin{tabular}{cccc}
\hline Treatment & Texture & Odor & Color \\
\hline VC & 7.25 & 5.50 & 4.75 \\
BA & 6.75 & 5.50 & 6.75 \\
AC & 6.30 & 5.70 & 5.50 \\
MS & 6.50 & 6.70 & 5.50 \\
TP & 5.25 & 4.50 & 4.50 \\
\hline
\end{tabular}

Note $: \mathrm{VC}=$ Supernatant of $V$. chiguensis; $\mathrm{BA}=$ Supernatant of B. aquimaris; $\mathrm{AC}=$ Supernatant of $V$. chiguensis and B. aquimaris co-culture; MS = Liquid Media; TP = No Sterilized Immersion.

Tabel (1) shows the average scores of Pacific mackerel meat odor in which MS treatment resulted in the highest score at 6.5. Whereas $\mathrm{VC}, \mathrm{BA}$, and $\mathrm{AC}$ treatments recorded scores ranging from 5.5 to 5.7. The lowest score was found in the meat without treatment at 4.5. This result showed different scores given by the panelists to each treatment group sample, with samples from treatment group emitting common fish meat odor while the non-treatment sample gave out a strong, putrid odor. The value of the MS control group indicated the effect of the liquid media on the meat. Moreover, the supernatant of sea cucumber symbiont bacteria indicated an inhibitition of a degradation process due to its bactericidal properties. 
Table (1) shows average scores of Pacific mackerel meat color. The highest score for meat color was awarded to BA treatment group at 6.75. While VC, AC and MS treatment groups obtained $4.75,5.5$, and 5.5 respectively. The meat with no treatment obtained the lowest score with a value of 4.5 . The scores given by the panelists indicated that the treatment resulted in red to pale red colors, whereas the meat with no treatment was observed to be dark red.

\section{Acidity and Colony Count}

The lowest acidity was found in VC at 5, and the highest acidity was found in TP at 6.33 (Table 2 ). Almost all treatments resulted in $\mathrm{pH}$ values under 7 (neutral). The results of total plate count in Pacific mackerel meat are presented in Table (1). The results indicated that $\mathrm{VC}$ had the least colony count $(6.4 \times 105$ colony/g). The acidity in sample with VC treatment was thought to be the contributing factor in low contaminant bacterial growth. The highest colony count was found in TP with $92.2 \times 10^{5}$ colony/g.

Table 2. Acidity of Pacific Mackerel Meat and Colony Count

\begin{tabular}{ccc}
\hline Immersion Treatment & $\mathbf{p H}$ & (colony/g) \\
\hline VC & 5 & $6.4 \times 10^{5}$ \\
BA & 6 & $10.7 \times 10^{5}$ \\
AC & 6 & $17.8 \times 10^{5}$ \\
MS & 5.67 & $7.8 \times 10^{5}$ \\
TP & 6.33 & $92.2 \times 10^{5}$ \\
\hline
\end{tabular}

Note $: \mathrm{VC}=$ Supernatant of $V$. chiguensis $; \mathrm{BA}=$ Supernatant of $B$. aquimaris $; \mathrm{AC}=$ Supernatant of $V$. chiguensis and B. cquimaris co-culture; MS = Liquid Media; TP $=$ No Sterilized Immersion.

The high acidity of TP meat was thought to be the cause of rapid proliferation of bacterial colony. The bactericidal compounds in the supernatant were attributed to the low rate of bacterial growth.

\section{Chemical Assay}

The highest water content was found in BA treatment at $77.28 \%$, whereas the lowest was found in AC treatment at $72.98 \%$ (Table 3). The immersion treatment was believed to be the contributing factor of high water content in meat, in addition to low storage temperature at $4{ }^{\circ} \mathrm{C}$. Low storage temperature correlates directly with high water content in the meat, since the lower the temperature is, the more water the meat retains. 
Table 3. Chemical Assay of Pacific Mackerel Meat

\begin{tabular}{cccccccc}
\hline Treatment & $\begin{array}{c}\text { Water } \\
\text { Content } \\
(\boldsymbol{\%})\end{array}$ & $\begin{array}{c}\text { Ash } \\
\text { Content } \\
(\boldsymbol{\%})\end{array}$ & $\begin{array}{c}\text { Fat } \\
\text { Content } \\
(\boldsymbol{\%})\end{array}$ & $\begin{array}{c}\text { Protein } \\
\text { Content } \\
(\boldsymbol{\%})\end{array}$ & $\begin{array}{c}\text { Carbohydrate } \\
\text { Content }(\boldsymbol{\%})\end{array}$ & $\begin{array}{c}\text { TVB-N } \\
(\mathbf{m g N} \%)\end{array}$ & $\begin{array}{c}\text { TMA-N } \\
(\mathbf{m g N} \%)\end{array}$ \\
\hline VC & 77.00 & 1.04 & 0.81 & 19.19 & 1.96 & 41.24 & 18.46 \\
BA & 77.82 & 1.13 & 0.73 & 19.16 & 1.16 & 53.35 & 29.04 \\
AC & 72.98 & 1.21 & 0.92 & 22.6 & 2.29 & 43.93 & 22.44 \\
MS & 74.67 & 1.32 & 1.71 & 20.74 & 1.56 & 48.57 & 22.86 \\
TP & 76.32 & 0.43 & 1.34 & 21.77 & 0.14 & 33.2 & 12.56 \\
\hline
\end{tabular}

Note $: \mathrm{VC}=$ Supernatant of $V$. chiguensis $; \mathrm{BA}=$ Supernatant of $B$. aquimaris $; \mathrm{AC}=$ Supernatant of V. chiguensis and B. aquimaris co-culture; MS = Liquid Media; TP $=$ No Sterilized Immersion

Histidine Analysis

The Histidine analysis in this study indicated that the treatment with sterilized liquid media resulted in $0.217 \%$ histidine content (Table 4). The most desirable result of histidine content was found in $\mathrm{VC}$ treatment group with $0.38 \%$, followed by $\mathrm{BA}$ treatment group with $1.038 \%$ and AC treatment group with $1.049 \%$.

Table 4. Histidine Content of Pacific Mackerel Meat

\begin{tabular}{cc}
\hline Sample Code & Histidine Content (\%) \\
\hline VC & 0.384 \\
BA & 1.083 \\
AC & 1.049 \\
MS & 0.217 \\
TP & 0.291 \\
\hline
\end{tabular}

Note $: \mathrm{VC}=$ Supernatant of $V$. chiguensis; $\mathrm{BA}=$ Supernatant of $B$. aquimaris $; \mathrm{AC}=$ Supernatant of V. chiguensis and B. aquimaris co-culture; MS = Liquid Media; TP = No Sterilized Immersion

\section{Histology of Pacific Mackerel Meat}

The results indicated that the tissue samples with $V$. chiguensis supernatant, B. aquimaris supernatant, and from Sterilized liquid media treatment groups retained good tissue structures. However, meat treated with B. aquimaris supernatant and $V$. chiguensis co-culture supernatant, as well as meat without treatment showed necrosis and fat degeneration in their tissues. This means that the tissues from the products in both groups were damaged (Figure 1). 



Note: NR (Necrosis); DL (Fat Degeneration); DH (Hyaline Degeneration)

Figure 1. Histology of Pacific mackerel meat tissue at $400 \mathrm{x}$ magnification; (A) immersion treatment using B. aquimaris supernatant; (B) immersion treatment with $V$. chiguensis supernatant; (C) immersion treatment with B. aquimaris and $V$. chiguensis co-culture supernatant; (D) immersion treatment with sterilized liquid media; (E) no immersion treatment

The HDC gene in the visualization was indicated by 700 bp marker. Similar patterns were visually observed in all samples, namely VC treatment group, BA treatment group, AC treatment group, MS control group, and TP control group, as presented in Figure (2). Band comparison of samples across all groups indicated that the marker band matched the sample bands. 


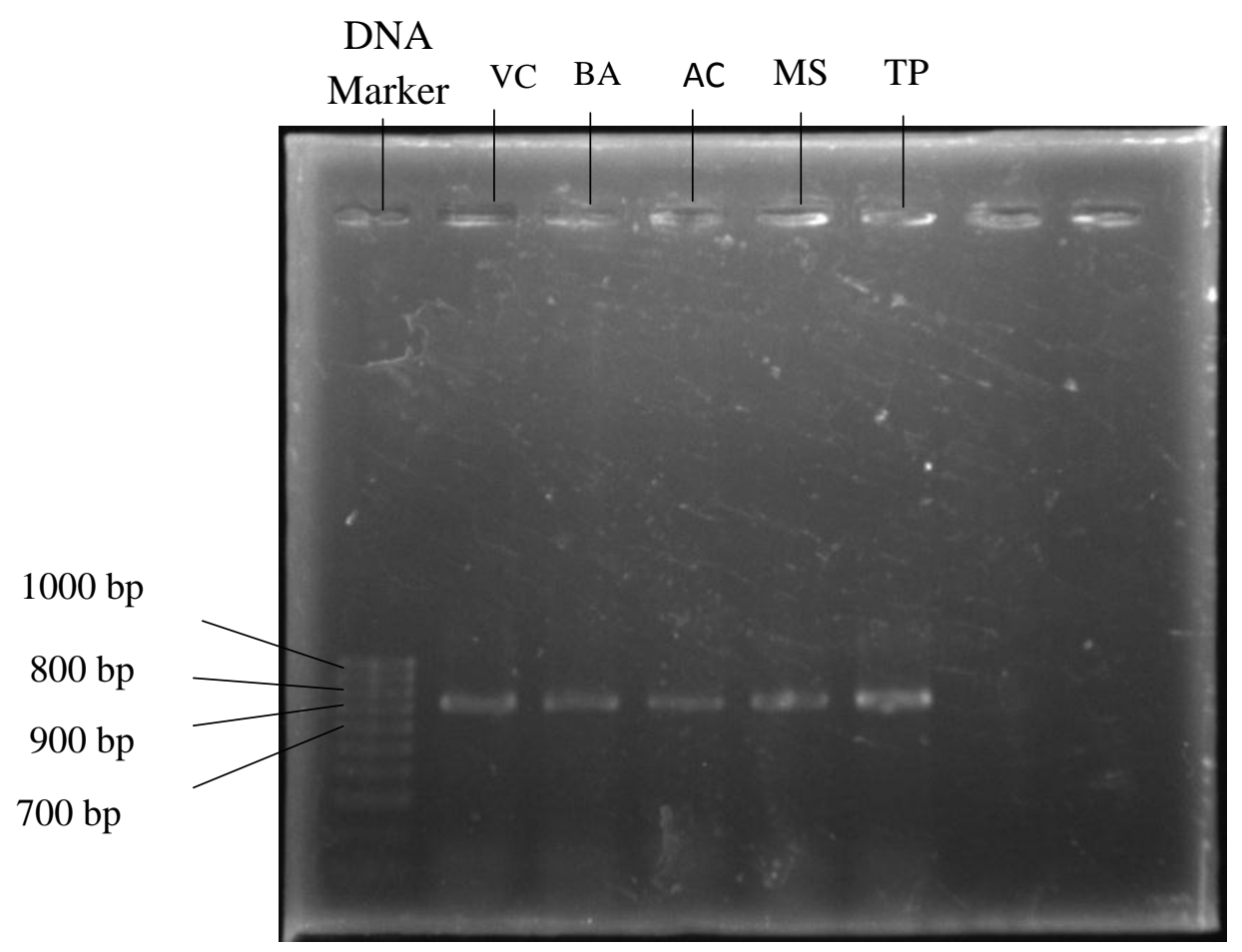

Figure 2. Electrophoresis result of Rep-PCR amplification product visualization

\section{DISCUSSION}

\section{Organoleptic Assessment}

The pathogen of bacteria used the protein content of the meat as their source of nutrition, caused a gradual change of meat structure. The enzymes from bacterial activity during the storage contributed to the texture breakdown, allowing the bacterial colony to proliferate and adversely affect the product quality (Dwetro et al., 2017). Texture is defined as the way in which the constituent components and structural elements are arranged and combined into micro and macrostructure, and present the reality of this structure out in terms of flow and deformation (Budaraga et al., 2016). The texture of the meat deteriorates as the binding tissues of the meat egrade. The antibacterial compounds in the supernatant contributed to hinder the growth of contaminant bacteria, which resulted in the preservation of meat texture. The Indonesian National Standard (SNI) establishes a minimum score of 7 on texture for meat product safety, which means that the treatment result of this study succeeded to meet the standard for further processing.

The activity of the contaminant bacteria on the meat was thought to be the cause of the strong, unpleasant odor. The fresh fish fillets had a specific fresh smell, while the rotten fish fillets had a harsh malodorous odor of ammonia (Budaraga, 2016). Amaral et al. (2018) attributed the putrid odor of the meat to the fat oxidation process. This 
process produces ammonia, which is known to emit putrid odor. Indonesian National Standard (SNI) establishes a minimum score of 6.5 on odor for meat product safety. This score was given to MS treatment group. However, the treatment could not be applied in the meat preservation as it was the control group in this study. All immersion treatments with supernatants did not meet this standard.

The treatment sample groups consistently showed lighter coloration compared to the sample with no treatment. The supernatant used in the immersion treatment contributed to this result by slowing down meat degradation. The antibacterial compound in the supernatant lowered the growth rate of contaminant bacteria in the meat. Color has a drastic effect on the perception of flavor because the information that is received from eyes will lead to an expected flavor based on the color of a food, and that initial assumption can override the information received from our taste buds and olfactory system (Opeña et al., 2017).

\section{Acidity and Colony Count}

TP fish meat did not have the antibacterial compound, making the growth of contaminant bacteria significantly faster. The antibacterial compounds can lower the enzyme production from the proliferation of the contaminant bacteria (Egorov et al., 2018). Contaminant bacteria will continue to grow along with autolysis. This process involves protein-degrading enzymes from the fish which allow contaminant bacteria to break down protein even faster. The environmental factor during storage also plays an important role in the rate at which contaminant bacteria proliferate (Dwetro et al., 2017). Based on the current results, the bacterial colony count of the fish meat did not meet the standard set out in SNI 2729:2013, where the maximum colony count for any meat product deemed safe for consumption is $5 \times 10^{5}$ colony/g. Therefore, the TPC count from this study did not meet the safe standard for consumption.

Pre-rigor mortis meat has a $\mathrm{pH}$ value of 7 (Kim et al., 2014; Álvarez et al., 2019). Acidity value lower than 7 will inhibit the growth of several species of contaminant bacteria. This finding is in accordance with that of Cotter and Hill (2003), who stated that bacteria cannot grow ideally in acidic environments ( $\mathrm{pH}$ value $<7$ ), except for some species which can still thrive in such environments. Contaminant bacteria grow well in environments with optimum acidity, with $\mathrm{pH}$ value between 7 and 7.5. Low $\mathrm{pH}$ value resulting from immersion treatment was thought to be caused by the existence of acidic compound in the supernatant of sea cucumber symbiont bacteria. This acidic compound enhances the acidity of the meat, making it a non-ideal environment for the growth of contaminant bacteria. The $\mathrm{pH}$, as an index, is important to determin the quality of fish, thus, it can be used as a guide (Abbas et al., 2008; Gonçalves, 2017); . The $\mathrm{pH}$ of fish flesh and gills has an important influence on its freshness because of its influence on bacterial growth (Obemeata \& Christopher, 2012).

The results of total plate count in Pacific mackerel meat are presented in Table

(2). The results indicated that $\mathrm{VC}$ had the least colony count at $6.4 \times 10^{5}$ colony/g. The 
acidity in the sample with VC treatment was thought to be the contributing factor in low contaminant bacterial growth. The highest colony count was found in TP with $92.2 \times 10^{5}$ colony/g. The high acidity of TP meat was thought to be the cause of rapid proliferation of bacterial colony. The bactericidal compounds in the supernatant were attributed to the low rate of bacterial growth. The TP fish meat did not have these compounds, making the growth of contaminant bacteria significantly faster. The antibacterial compounds can lower the enzyme production from the proliferation of contaminant bacteria (Egorov $\boldsymbol{e t}$ al., 2018). Contaminant bacteria will continue to grow along with autolysis. This process involves protein-degrading enzymes from the fish which allow contaminant bacteria to break down protein even faster. The environmental factor during storage also plays an important role in the rate at which contaminant bacteria proliferate (Dwetro et al., 2017). Based on the results, the bacterial colony count of the fish meat in this study did not meet the standard set out in SNI 2729:2013, where the maximum colony count for any meat product deemed safe for consumption is $5 \times 10^{5}$ colony/g. Therefore, fresh fish quality requirements, based on SNI standards, are to have a TPC value of $5 \times 10^{5} \mathrm{CFU} / \mathrm{g}$ or equivalent to $5.70 \log \mathrm{CFU} / \mathrm{g}$. This shows that the fish is not suitable for consumption. This is presumably because the salmon is contaminated with pathogenic microbes that develop in the fish's body.

\section{Chemical Assay}

The high water content in the air of the storage chamber can also cause an increase in the water content of the meat (Mathlouthi, 2001; Guiné, 2018). During the treatment phase, the supernatant, which is rich with secondary metabolites from the symbiont bacteria, was introduced into the meat tissue. The SNI has established a maximum water content of 60-65\% for safe-to-consume meat products, a standard which the meat in this study did not meet. Water content significantly impacts meat quality and its shelf-life. High water content in meat directly contributes to the rapid deterioration of color, odor and texture during storage (Aidani et al., 2014). High water content also causes rapid proliferation of contaminant bacteria colony, which further lowers the quality of the meat (Cabral, 2010; Agus et al., 2014). The lower the water content of the meat is, the longer the shelf-life will be and vice-versa (Katiandagho et al., 2017).

\section{Histology of Pacific Mackerel Meat}

Tubular cell necrosis is usually caused by ischemic and nephrotoxic agents. Vasoconstriction and reduced blood flow that cause ischemia result in tubular cell damage (Ahmadmoradi et al., 2012). This is caused by the cathepsin enzyme, whose activity increases during the setback process quality, thereby causing the protein band to degrade and look thinner. Cathepsins are the most abundant lysosomal proteases that are mainly found in acidic endo/lysosomal compartments where they play a vital role in intracellular protein degradation, energy metabolism, and immune responses among a host of other functions (Yadati et al., 2020). This is caused by the Cathepsin enzyme, whose enzyme activity will increase during the setback process quality, thereby making 
the protein band degraded and look thinner. Cathepsins are the most abundant lysosomal proteases that are mainly found in acidic endo/lysosomal compartments where they play a vital role in intracellular protein degradation, energy metabolism, and immune responses among a host of other functions (Yadati et al., 2020).

\section{CONCLUSION}

The study indicated that Virgibacillus chiguensis found in the intestines of sea cucumbers showed potential in its application to be a bactericide of contaminant bacteria in the Pacific mackerel (Scomber japonicus) meat's preservation process.

\section{REFERENCES}

Abbas, K. A.; Mohamed, A., Jamilah, B. and Ebrahimian, M. (2008). A review on correlations between fish freshness and $\mathrm{pH}$ during cold storage. Am. J. Biochem. Biotechnol. 4(4): 416-421.

Ahmadmoradi, E.; Rezaie, A. and Mousavi, S. M. (2012). Histopathological study of the kidney, liver and intestine tissues in goldfish (Carassius auratus) and angelfish (Pterophyllum sp.). AACL Bioflux., 5(4): 282-288.

Agus, C.; Faridah, E.; Wulandari, D. and Purwanto, B. H. (2014). The role of microbial starter in animal dung decomposition and manure quality improvement). $\mathbf{J}$. Manusia dan Lingkungan., 21(2):179-187. (In Indonesian)

Aidani, E.; Aghamohammadi, B.; Akbarian, M.; Morshedi, A.; Hadidi, M.; Ghasemkhani, N. and Akbarian, A. (2014). Effect of chilling, freezing and thawing on meat quality: A review. International Journal of Biosciences (IJB), 5(4), $159-169$.

Allaya, H.; Hattour, A.; Hajjej, G. and Trabelsi, M. (2013). Biologic characteristics of Scomber japonicus (Houttuyn, 1782) in Tunisian waters (Central Mediterranean Sea). African J. Biotechnol., 12(20): 3040-3048.

Álvarez, C.; Morán, L.; Keenan, D. F.; Mullen, A. M. and Delgado-Pando, G. (2019). Mechanical and Biochemical Methods for Rigor Measurement: Relationship with Eating Quality. J. Food Qual., 2019:1-14.

Amaral, A. B.; Solva, M. V. D. and Lannes, S. C. D. S. (2018). Lipid oxidation in meat: Mechanisms and protective factors - a review. Food Sci. Technol., 38: 1-15.

AOAC [Official Methods of Analysis of AOAC International], 18th Edition. (2005) AOAC International.

Brillantes, S.; Paknoi, S. and Totakien, A. (2002). Histamine formation in fish sauce production. J. Food Sci., 67(6): 2090-2094.

Budaraga, I. K.; Arnim, Marlida, Y. and Bulanin, U. (2016). Analysis of liquid smoke chemical components with GC MS from different raw materials variation production 
and pyrolysis temperaturelevel. Int. J. ChemTech Res., 9(6): 694-708.

Cabral, J. P. S. (2010). Water Microbiology. Bacterial Pathogens and Water. Int. J. Environ. Res. Public., 7: 3657-3703.

Cotter, P.D. and Hill, C. (2003). Surviving the acid test: responses of gram-positive bacteria to Low pH. Microbiol Mol Biol Rev., 67(3): 429-453.

Deviyanti, P. N.; Dewi, E. N. and Anggo, A. D. (2015). Efektivitas daun kemangi (Ocimum sanctum 1.) sebagai antibakteri pada ikan kembung lelaki (Rastrelliger kanagurta) selama penyimpanan dingin. Jurnal Pengolahan Dan Bioteknologi Hasil Perikanan, 4(3): 25-32.

Dwetro, G. R.; Suparmi and Sumarto (2017). Pengaruh penambahan ekstrak daun kemangi terhadap daya awet ikan nila (Oreochromis niloticus) SEGAR. 1-13.

Egorov, A. M.; Ulyashova, M. M. and Rubtsova, M. Y. (2018). Bacterial Enzymes and Antibiotic Resistance. Acta Naturae, 10(39): 33-48.

FAO/WHO. (2012). Joint FAO/WHO Expert Meeting on the. In Public healt risks of histamine and other biogenic amines from fish and fishery products.

Farouk, A. E. A.; Ghouse, F. A. H. and Ridzwan, B. H. (2007). New bacterial species isolated from Malaysian sea cucumbers with optimized secreted antibacterial activity. Am. J. Biochem. Biotechnol., 3(2): 60-65.

Fitri, D. S.; Pangastuti, A. and Susilowati, A. R. I. (2017). Endophytic bacteria producing antibacterial against methicillin- resistant Staphylococcus aureus ( MRSA ) in seagrass from Rote Ndao , East Nusa Tenggara , Indonesia. Biodiversitas., 18(2): 733-740.

Gonçalves, A. A. (2017). The PH of the Seafood Meat: A Problem that Deserves to be Clarified. MOJ Food Process. Technol., 4(1): 25-26.

Guiné, R. P. F. (2018). The Drying of Foods and Its Effect on the Physical-Chemical, Sensorial and Nutritional Properties. Int. J. Food Eng., 4(2): 93-100.

Hernández, J. J. C. and Ortega, A. T. S. (2000). Synopsis of Biological Data on The Chub Marckerel (Scomber japonicus Houttuyn, 1782). FAO Fishery Synopsis, 157: $1-77$.

Ibrahim, H. A. H. (2012). Antibacterial carotenoids of three Holothuria species in Hurghada, Egypt. Egypt. J. Aquat. Res., 38(3): 185-194.

Idakwo, P.Y.; Negbenebor, C.A.; Badau, M.H., and Gbenyi DI. 2016. Total volatile base nitrogen (TVBN) and trimethylamine (TMA) content of "Bunyi youri" as influenced by the addition of glucose and clove during storage. Int. J. Biotechnol. Food Sci.., 4(5):. 81-85

Kanki, M.; Yoda, T.; Tsukamoto, T. and Baba, E. (2007). Histidine decarboxylases and their role in accumulation of histamine in tuna and dried saury. Appl. Environ. Microbiol., 73(5): 1467-1473.

Katiandagho, Y.; Berhimpon, S. and Reo, A. R. (2017). Pengaruh Konsentrasi Asap Cair Dan Lama Perendaman Terhadap Mutu Organoleptik Ikan Kayu (Katsuo- 
Bushi). Media Teknologi Hasil Perikanan., 5(1): 1-7.

Kim, Y. H. B.; Warner, R. D. and Rosenvold, K. (2014). Influence of high pre-rigor temperature and fast $\mathrm{pH}$ fall on muscle proteins and meat quality: A review. Anim. Prod. Sci., 54(4):375-395.

Malenfanta, D. J.; Paulick, A. E. and Rehse, S. J. (2019). A simple and efficient centrifugation filtration method for bacterial concentration and isolation prior to testing liquid specimens with laser-induced breakdown spectroscopy. Spectrochimica Acta - Part B Atomic Spectroscopy, 158.

Mathlouthi, M. (2001). Water content, water activity, water structure and the stability of foodstuffs. Food Control., 12(7): 409-417.

Nahla, T. K. and Farag, H. E. M. (2005). Histamine and Histamine Producing Bacteria in Some Local and Imported Fish and Their Public Health Significance Microbiology Res. J. Agric. Biol. Sci., 1(4): 329-336.

Obemeata, O.; Nnenna, F.P. and Christopher, N. (2011). Microbiological assessment of stored Tilapia guineensis. Afr. J. Food Sci., 5(4): 242 - 247.

Opeña, A. M.; Baleta, F. N. and Bolaños, J. M. (2017). Sensory, organoleptic, and proximate composition of smoked surgeon fish Acanthurus sp . using selected herbs as flavor enhancer. Int. J. Food Sci. Nutr. 2(1):174-181.

Phillips, K.; Mccallum, N. and Welch, L. (2012). Forensic Science International: Genetics Short communication A comparison of methods for forensic DNA extraction: Chelex-100 1 and the QIAGEN DNA Investigator Kit ( manual and automated ). Forensic Sci. Int. Genet., 6: 282-285.

Pringgenies, D.; Rudiyanti, S. and Yudiati, E. (2018). Exploration of Sea Cucumbers Stichopus hermanii from Karimunjawa Islands as Production of Marine Biological Resources. IOP Conference Series: Earth and Environmental Science., 116:1-8.

Pringgenies, D.;Yudiati, E. Djunaedi, A. Santosa, G. W. and Koesoemadji. (2019). Explorations of symbiotic microbe from sea cucumber gut as an anti-multi-drug resistant microbe agent for utilization in hand sanitizer products. AACL Bioflux., 12(3):737-747.

Radjasa, O.K.; Urakawa, H, Kita-Tsukamoto K, and Ohwada, K. (2001). Characterization of psychrotrophic bacteria in the surface and deep-sea waters from the northwestern pacific ocean based on $16 \mathrm{~S}$ ribosomal DNA analysis. Mar. Biotechnol., 3: 454-462.

Santosa, G. W.;Djunaedi, A., Susanto, A. B. Pringgenies, D. and Ariyanto, D. (2020). Characteristics of bioactive compounds of Holothuria atra (Jaeger, 1833) associated bacteria. AACL Bioflux, 13(4):2161-2169.

Suzuki, N.; Tsujino, K. Minato, T. Okada, T. and Kataoka, T. (1993). Antibody mimicking the action of RAS Proteins on Yeast Adenylyl Cyclase : Implication for RAS-Effector Interaction. Mol. Cell. Biol., 13(2):769-774.

Takahashi, M and Tezuka, T. (1997). Quantitative analysis of histidine and cis and 
trans isomers of urocanic acid by high-performance liquid chromatography: a new assay method and its application J Chromatogr B Biomed Sci Appl., 688(2):197203.

Tinacci, L.; Armani, A. Guidi, A. Nucera, D. Shvartzman, D. Miragliotta, V. Coli, A. Giannessi, E. Stornelli, M. R. Fronte, B. Di Iacovo, F. and Abramo. F. (2018) Histological discrimination of fresh and frozen/thawed fish meat: European hake ( Merluccius merluccius) as a possible model for white meat fish species. Food Control, $92: 154-161$.

Yadati, T.;Houben, T. Bitorina, A. and Shiri-sverdlov, R. (2020). The ins and outs of cathepsins : physiological function and role in disease management. Cells, 9(1679): $1-26$.

Zhang, X.; Nakahara, T. Miyazaki, M. Nogi, Y. Taniyama, S. Arakawa, O. and Kudo, T. (2012). Diversity and function of aerobic culturable bacteria in the. J. Gen. Appl. Microbiol. 456:447-456. 